\title{
Impact of Intercropping Sorghum and Okra on the Incidence of Flea Beetles of Okra Podagrica spp in Dalwa, Maiduguri Semi-Arid Zone of Nigeria
}

\author{
M. M. Degri ${ }^{1, *}$, I. B. Richard ${ }^{2}$ \\ ${ }^{1}$ Department of Agronomy, Faculty of Agriculture, Federal University Kashere, Gombe State, Nigeria \\ Tel. +2340833622910 \\ ${ }^{2}$ Department of Crop Protection, Faculty of Agriculture, University of Maiduguri, Nigeria \\ *E-mail address: mikedegri@gmail.com
}

\begin{abstract}
Field experiments were conducted at faculty of Agriculture teaching and research farm, university of Maiduguri in 2010 and 2011 rainy seasons. The aim was to investigate the impact of intercropping sorghum with okra on the incidence of flea beetle of okra (Podagrica spp) in the semiArid zone of Nigeria. The results showed that sole crop okra suffered flea beetle attack which affected its growth, fruit formation, fruit weights and fruit yield. Intercropping okra with sorghum significantly reduced the flea beetle populations, leaf damage caused by Podagrica spp (Coleoptera: Chrysomelidae). While increasing number of leaves for photosynthetic activities, plant height, fruit formation, fresh fruit weight and total fruit yield. The study concluded that okra intercropping at 1:1, $1: 2$ and 2:2 are the most efficient and productive intercrop systems in flea beetle management. Okra intercropping with cereal sorghum was found to be good for sustainable agriculture and organic farming in Nigeria due to its numerous advantages, particularly with respect to insect pests' control.
\end{abstract}

Keywords: intercropping; sole cropping; okra; incidence; semi-arid; Podagrica spp

\section{INTRODUCTION}

Okra, Abelmoschus esculentus L. (syn. Hibiscus esculentus) is an important vegetable crop cultivated mainly for its young leaves, immature edible green fruits and mature seeds that are known for their high levels of vitamins A, C, calcium Iron, fibre, ascorbic acid, Rivoflavin (Ahmed et al., 2004; Christo and Onuh, 2005) okra belongs to the family Malvaceae and a popular vegetable crop which is grown all the year round in Nigeria for its good nutritional value (Clementine et al, 2009; Degri, 2010) it is a tropical plant which grows best in warm climates (Salau et al., 2012). Cultivation of the crop is done mainly by the poorresource farmers in Northern Nigeria who usually intercrop it with other crops (Anaso, 2003, Degri et al., 2012).

It is grown in gardens, behind houses, plain floods (Fadama) areas and under big trees (Degri, 2010). It is cultivated alone or intercropped with field crops like maize, Sorghum, yams and cassava (Mumford and Baliddawa, 1982; Muoneke and Asiegbu, 1997; Ijoyah et al., 2012). 
Okra is vulnerable to insect pests during all stages of growth, however, severe damage is noticed especially during vegetative stage (Peter and David, 1988; Ogunlana et al, 2002; Anaso and Lale, 2001; Ahmed et al, 2007; Obeng- Ofori and Sankey, 2003; Fasunwon and Banjo, 2010; Alao et al., 2011). Insect pests are a major setback for commercial production of the crop in Adelana 1986; Hugar and Palled 2008; Ijoyah, 2012). Among the insect pests that cause economic damage on the crop, the flea beetle (Podagrica spp) (Coleoptera, Chrysomelidae) is the most serious in the recent times (Ahmed et al, 2007; Clementine et al, 2009; Fasunwon and Banjo, 2010).

Flea beetle of okra have constantly been observed as major pests of okra, infesting leaves leading to considerable economic yield losses. Degri, 2010; Fasunwon and Banjo, 2010). Defoliation due to flea beetle infestations has been reported to be up to $80 \%$ and severity of damage varies in different places (Egwuatu, 1982, Clementine et al., 2009). The act activity of flea beetle drastically reduces the photosynthetic capacity of the leaf resulting in low dry matter production and consequently, low yield (Osisanya and Taylor, 1981; Thul et al., 2009). It has been reported that flea beetles are responsible for the transmission of okra mosaic virus (OMV) observed in Nigeria, Kenya, Sierra Leone, Cote d'Ivoire (Fajinmi and Fajinmi 2010, Askira and Degri, 2012).

Due to the destructive activities of the flea beetle, their management becomes imperative in order to achieve and maintain yields. In the past, various control measures have been adopted, such as use of insecticides (Emosairue and Ukeh, 1997; Egwuatu, 1982; Anaso, 2003). Generally synthetic insecticides are the most effective means due to their quick action and long lasting effects Ahmed et al., 2007 Emosairue and Ukaegbu, 1994). Unfortunately, the high cost of pesticides is beyond the reach of the poor-resource farmers, most okra farmer are poor, illiterate and cannot adopt application of most insecticides (Nderitu et al., 2008; Thul et al, 2009; Ukoima and Okah, 2006). There is need to assess some control measures that are environmentally friendly, less costly, easy to apply and easy to adopt such as intercropping, host plant resistance and other cultural practices (Obeng-Ofori and Sanckey, 2003, Osisanya and Tayor, 1981).

Although the use synthetic and botanical insecticides for the control of Podagrica spp has been reported in Nigeria, but there is paucity of information on the effect of intercropping of okra with cereals for the purpose of managing Podagrica spp in the semi-arid zone of Nigeria, thus the aim of this study.

\section{MATERIALS AND METHODS}

Field experiments were conducted at Faculty of Agriculture Teaching and Research farm, University Maiduguri situated at $11^{\circ} 51^{\prime} \mathrm{N}$ and $13^{\circ} 15^{\prime} \mathrm{E}$ in 2010 AND 2011 rainy seasons.

The experimental field was cleared, ploughed, harrowed and levelled. The experiments consisted of five intercrop patterns (1.0 sole okra), 1:1 (one row of okra and one row of sorghum); 2:1 (one row of okra and row of sorghum), 2:2 (two rows of okra two rows of sorghum) laid out in randomized complete block design and replicated four times. The net plot sizes were $4.0 \mathrm{~m} \times 3.0 \mathrm{~m}\left(120 \mathrm{~m}^{2}\right)$.

The okra (Lady's finger) and sorghum (Borno Brown) seeds were obtained from Borno State Agricultural Development Programme (BOSADP) input store location in the Ministry of Agriculture, Maiduguri. 
The sorghum seeds were planted in July during the two years at the rate of 4 seeds per stand at $75 \mathrm{~cm} \times 25 \mathrm{~cm}$ spacing while okra seeds were planted at the rate of 3 seeds per stand during both years. After germination, sorghum over-seed and okra plant were later thinned to 2 plants per stand during first weeding to minimize overcrowding and empty gaps were filled to maintain a normal plant population in the experimental field. Fertilizer (NPK 20:10:10) was split-applied to the crops at 2 weeks after sowing (WAS) and 6WAS. Weeding and all other agronomic practices were timely carried out.

Data on number of flea beetles/plant, plant height, percentage of leaves/plant, number of pods/plant, weight of pods/plant, damaged fruits and fresh pod yield.

Flea beetles being one of the major defoliators of okra plant were counted on 10 randomly selected okra plants per plot. The counting was done three times at the stages of seedling, full vegetative and flowering/fruiting respectively between 6:00 am - 8:00 am when the flea beetles have not gone into hiding.

Number of leaves damaged by flea beetles was counted on 10 randomly selected okra plants per plot. Okra leaves being the major plant part that flea beetles feed, were observe during the three stages (seedling, vegetative and reproductive) and all leaves were counted and those damaged were also counted. The damaged leaves were converted to percentage / plant and recorded.

$$
\% \text { Leaves Damage }=\frac{\text { Total No. of damaged leaves } / \text { plant }}{\text { Total No. of health leaves }- \text { damaged leaves }} \times 100
$$

Flea beetles are known to affect plant growth. Plant height of 10 randomly selected okra plants were measured using plastic measuring tape in centimetres and recorded. Number of pods per plant was counted from the 10 randomly selected okra plants. Okra pods being the main yield parameter used were counted and recorded.

Flea beetles defoliation affects reproductive structures due reduction in photosynthesis and growth. The weight of okra pods per plant were taken by weighing them after each harvest using metler balance (model 2000) and recorded. The weight of fresh okra also is affected by the feeding activity of flea beetles on okra.

The weight of the fresh okra fruits were all collected at each harvest and weighed immediately using metler balance scale and recorded. All the data collected were subjected to analysis of variance (ANOVA). The intercropping patterns were compared and separately using least significant difference (LSD) at $5 \%$ level of probability.

\section{RESULTS}

\section{1. Impact of sorghum okra intercrop on Podagrica spp populations}

The population of flea beetle on sole and in intercrop with sorghum results is presented in Table 1.

Flea beetle populations were significantly higher in sole okra (1:0) than in intercrop plots. Okra planted at 1:2 (one okra row to two sorghum rows) had significantly the lowest flea beetle populations during the study period. Okra planted at ratio proportions of $1: 1$ and 2:2 had moderate flea beetle populations. 
Table 1. Effect of intercropping okra on Podagrica spp. population.

\begin{tabular}{|cc|}
\hline Intercrop pattern & Podagrica spp populations \\
\hline $1: 0$ & 19.33 \\
$1: 1$ & 14.56 \\
$1: 2$ & 10.17 \\
$2: 1$ & 15.33 \\
$2: 2$ & 14.36 \\
SE $+/-$ & 0.31 \\
LSD $(0.05)$ & 0.67 \\
\hline
\end{tabular}

\section{IMPACT OF SORGHUM OKRA INTERCROP ON NUMBER OF LEAVES/ PLANT, PERCENTAGE NUMBER OF LEAVES DAMAGE AND PLANT HEIGHT}

Number of leaves/plant were lowest on okra planted as sole (1:0) while okra planted in intercrop ratio proportions of 1:2 (one okra row to two sorghum rows) had significantly the highest number of leaves/plant (Table 2). Okra planted at the ratio proportions of 1:2 and 2:2 had statistically the same number of leaves /plant. The percentage of number of leaves damaged/plant were significantly higher $(58.72 \%)$ followed by $2: 1(53.86 \%)$ intercrop pattern while okra planted in intercrop of 1:2 had the lowest percentage number of leaves damaged plant $(39.58 \%)$. There was no significant difference between okra planted in intercrop of 1:1 and 2:2 when compared during the study period (Table 2).

When the okra plant heights were compared, okra planted in intercrop of 1:2 had significantly the highest plant height $(87.61 \mathrm{~cm})$ followed by okra planted in intercrop of 2:1 with plant height of $86.52 \mathrm{~cm}$ (Table 2). Okra planted as sole crop had significantly the lowest plant height $(77.62 \mathrm{~cm})$.

Table 2. Effect of intercropping okra on number of leaves/plant, percentage number of leaves of damage and pant height.

\begin{tabular}{|cccc|}
\hline Intercrop pattern & no. Of leaves/pant & \% no. Of leaves damaged/plant & plant height (cm) \\
\hline $1: 0$ & 8.48 & 58.72 & 77.62 \\
$1: 1$ & 10.79 & 46.81 & 85.33 \\
$1: 2$ & 13.62 & 39.58 & 87.61 \\
$2: 1$ & 10.27 & 53.86 & 86.52 \\
$2: 2$ & 9.56 & 47.13 & 84.80 \\
SE + - & 0.31 & 8.67 & 0.21 \\
LSD $(0.05)$ & 0.67 & 19.14 & 0.43 \\
\hline
\end{tabular}

\section{IMPACT OF SORGHUM-OKRA INTERCROP ON NUMBER OF FRUITS/ PLANT, FRESH FRUIT WEIGHT/PLANT AND FRUIT YIELD/PLOT}

Mean number of fruits/plant recorded under okra planted in intercrop 1:2 produced significantly the highest mean number of fruits/plant followed by okra planted in intercrop 1:1 (Table 3). Okra by okra planted as sole crop produced the lowest fruit per plant while 
okra planted in intercrop of 2:1 and 2:2 had significantly produced moderate number of fruits/plant and they were not significantly difference from each other.

Means fresh weight of fruits/plant and mean fruit yield/plot compared during the study period showed that okra planted as sole crop had significantly the lowest mean fruit weight and mean fruit yield of $10.17 \mathrm{~g}$ and $316.72 \mathrm{~kg} / \mathrm{ha}$ respectively (Table 3). Okra planted in intercrop ratio proportion of 1:2,1:1 and 2:2 had fruit weights and mean fruit yield of $19.33 \mathrm{~g}$, $15.30 \mathrm{~g}$ and $14.66 \mathrm{~g}$ fresh weights corresponding to $1618.10 \mathrm{~kg} / \mathrm{ha}, 1310.41 \mathrm{~kg} / \mathrm{ha}$ and $1268.29 \mathrm{~kg} / \mathrm{ha}$ mean fruit yield in that order.

Table 3. Effect of intercropping okra on number of fruits, fresh weight of fruit yield.

\begin{tabular}{|cccr|}
\hline Intercrop pattern & No. Of fruits/plant & fresh weight of fruits/plant (g) & fruit yield $\mathbf{~ k g} / \mathbf{h a}$ \\
\hline $1: 0$ & 3.22 & 10.17 & 316.72 \\
$1: 1$ & 7.10 & 15.30 & 1310.41 \\
$1: 2$ & 9.87 & 19.33 & 1618.10 \\
$2: 1$ & 4.13 & 14.36 & 971.16 \\
$2: 2$ & 5.21 & 14.66 & 1268.29 \\
SE+/- & 0.04 & 0.31 & 16.74 \\
LSD $(0.05)$ & 0.09 & 0.67 & 36.48 \\
\hline
\end{tabular}

\section{DISCUSSION}

Okra planted as sole crop $(0: 1)$ had the highest flea beetle populations because there was no barrier and life cycle interference against the breeding and spread of the flea beetle within the okra crops (Trenbath, 1993). Intercropping okra is known to be very promising cultural practise in the reduction and control of pests. One component crop of an intercropping system act as a barrier against the spread of pest (Ijoyah, 2012). The lower and moderate populations of Podagrica species recorded in intercrop okra plants indicate that intercropping cereals with vegetables not only offers the poor-resource farmers insurance against crop failure. It also helps control insect infestation and weeds (Ijoyah and Jimba, 2012; Ijoyah and Fanen, 2012). Uddin II and Odebiyi (2011) reported that intercropping reduces the incidence of pest and diseases and the significance of their damage. Ahmed et al (2004) and Ijoyah (2012) reported that increased shading and humidity and reduced temperature brought about by some crop mixtures favour high population of some foliage beetles such as the flea beetle, Podagrica species. Broad (2007) reported that intercropping field vegetables with other crop species or engaging in mixed cropping systems manifest in insect pest suppression.

The lowest number of leaves/plant and highest percentage number of leaves damaged in sole planted okra could be due to low photosynthetic activity of okra leaves (Ahmed et al, 2004; Mumford and Baliddawa, 1982,Altieri and Nicholls, 1999). Okigbo and Greenland (1998) reported that farmers in Africa practice intercropping because it gives higher growth performance, higher vegetative growth and higher total yields and greater returns than the same crop grown under monocropping system. Growing okra plant under sole cropping condition lead to serious defoliation and subsequent yield reduction (Theunisseu, 1994, Muoneke and Asiegbu, 1997; Broad, 2007, Banfu and Mochiah, 2011). Okra leaves damage caused by the flea beetles reduced the photosynthetic capacity of leaves which was manifested in the lower plant heights, number of fruit/plant, light fresh fruit weights and 
lower fruit yield obtained from sole okra planted plots that suffered more insect damage ( Adelana, 1986, Pitan and Esau 2014, Clue, 1993, Pitan and Odebiyi, 2001, Willey et al, 1993 Olasantan and Lacas, 1992, Ijoyah and Dzer, 2012, Ijoyah et al, 2012). Crops planted as sole generally have greater efficiency in utilizing the growth environment, thus promoting a larger leaf area that could even encourage or attract leaf feeding beetles, and thus the low number of fruits and low fruit yield recorded under sole okra planted plots in this study (Ijoyah et al., 2012).

The okra fruit yield loss was higher in the sole crop, probably due to the activities of flea beetles which were not having been present in large populations in the intercropped okra plots. In fact, the percentage number of leaves damaged, fresh weight loss and lower fruit yield were noted most on sole okra plots than in intercropped plots that has more rows than others $(2: 1)$. The possible reason for the good performance of okra planted in intercrop was due to the low flea beetle populations while the reason for poor performance of okra planted as sole crop could be attributed to the high flea beetle populations (Ahmed et al, 2004, UddinII and Odebiyi, 2011). Intercropping of vegetables with cereals could therefore be seen as an option that fits well into the non -pesticide management of crops or organic agriculture that is currently gaining popularity among vegetable growers or organic gardening intercropping helps to keep crop cultivation costs to the barest minimum and avoid dependency on synthetic agrochemicals by utilizing cultural practices and materials that are readily available, easy to adopt and friendly to farmers.

\section{CONCLUSIONS}

Intercropping is the agricultural practice of cultivating two or more crops in the same space at the same time. A practice often associated with sustainable agriculture and organic farming. It benefits crop yield; control some kind of pests, increase crop productivity per unit area of land and other agronomic benefits. This study have shown that intercropping okra at the ratio proportions of 1:2,1:1 and 2:2 has serious impact on the general growth and yield performance of okra. Damage in the intercrop was significantly lower from that of okra in the sole crop. It is therefore advantageous intercropping cereals with vegetable okra to poor resource farmers. This is associated with a greater flea beetle population reduction, greater photosynthetic activity and greater total intercrop yield. It is however recommended that further studies be conducted on wider combination of okra and other cereal crops and other crop families in different locations and in different seasons within the savannah and arid agro-ecological zones of Nigeria.

\section{References}

[1] Adelana B.O. (1986). Neighbour effects in maize-okra mixed cropping. In paper presented at HORTSON $8^{\text {th }}$ Annual conference Ibadan. $10^{\text {th }}-14^{\text {th }}$ November, 9.

[2] Ahmed B.I., Yusuf S.R., Garba A.A., Mustapha S., Emirate Journal of Agricultural Science 18(1) (2004) 1-10.

[3] Ahmed B.I., Onu I., Hamiche B.M., Ogidi J.A., Nigeria Journal of Entomology 21 (2004) 1-10. 
[4] Ahmed B.I., Yusuf S.R., Yusuf A.U., Aliyu M., Global Journal of Agricultural Science 6 (2007) 31-34.

[5] Alao F.O., Adebayo T.A., Olaniran O.A., Akanbi W.B., Asian Journal of Plant Science and Research 1(3) (2011) 123-130.

[6] Altieri M.A., Nicholls C.I. (1999). Biodiversity, Ecosystem function and insect pest management in Agricultural systems. In Biodiversity in Agro-Ecosystem, Collins, W.W. and C.O. Qualset (Eds). CRC press, Boca Raton, Florida, pp: 69-84.

[7] Anaso C.E., Zeitchrift fur Angewandte Entomologie 98 (2003) 327-331.

[8] Anaso C. E., Lale N.E.S., Journal of Arid Agriculture 11 (2001) 65-72.

[9] Askira A.B., Degri M.M., Int. J. Agric. 4(1) (2012) 122-127.

[10] Banfu B., Mochiah M.B., Trends in Horticultural Research 2 (2011) 1-7.

[11] Broad S. (2007). Reducing chemical inputs in vegetable production systems using crop using crop diversification strategies. PhD Thesis, University of Tasmania, Australia.

[12] Christo E.I., Onuh M.O. (2005). Influence of plant spacing on the growth and yield of okra (Abelmoschus esculentus (L.) Moench). Proceedings of the $39^{\text {th }}$ conference of the Agricultural Society of Nigeria (ASN) held at Benin, $9^{\text {th }}-13^{\text {th }}$ October, pp. 51-53.

[13] Clementine L.D, Malick N.B, Koussao S., Antoine S., African Journal of Agricultural Research 4(12) (2009) 1488-1492.

[14] Clue T.D., Flower Garden Magazine 1 (1993) 1-3.

[15] Degri M.M., African Journal of Agric. Res. Dev. 3(30) (2010) 86-89.

[16] Degri M.M., Sharah H.A., Dauda Z., Global Journal of Bio-science and Bio-technology 2(4) (2012) 480-484.

[17] Egwatu R.I., Tropical Pest Management 28(2) (1982) 115-121.

[18] Emosairue S.O., Ukaegbu G.C., J. App. Chem. and Agric. 1 (1994) 25-29.

[19] Emosairue S.O., Ukeh D. A., Global J. Pure Appl. Sci. 3 (1997) 13-19.

[20] Fajinmi A.A., Fajinmi O.B., Journal of General and Molecular Virology 2(1) (2010) 28-31.

[21] Fasunwon B.T., Banjo A.D., Research Journal of Agriculture and Biological Science 6(3) (2010) 283-288.

[22] Hugar H.Y., Palled Y.B., Karnataka Journal of Agricultural Science 21 (2008) 162-164.

[23] Ijoyah M.O., Scientific Journal of Crop Science 1(3) (2012) 55-62.

[24] Ijoyah M.O., Dzer D.M., Int. Sch. Res. Net. 10 (2012) 7-12.

[25] Ijoyah M.O., Jimba J., J. Bio.Env.sci 2(2) (2012) 38-44.

[26] Ijoyah M.O., Adagba E.O., Iorlamen T., Int. J. Curr. Res. 4(4) (2012) 59-63.

[27] Ijoyah M.O., Iorlamen T., Idoko J.A., Journal of National Science Research 2(6) (2012) 79-85.

[28] Muoneke C.O., Asiegbu J.E., J. Agron. Crop Sci. 179 (1997) 201-207. 
[29] Mumford J.D., Baliddawa C.W., Insect sci. Appl. 4(1/2) (1982) 59-64.

[30] Nderitu J.H., Kasina J.M., Kimenju J.W., Malange F., Journal of Entomology 5 (2008) 207-212.

[31] Obadoni B. O., Mensah J.K., Emua S.A., World Rural Observations 2(1) (2010) 66-74.

[32] Obeng-Ofori D., Sackey J., Ethiopian J. Sci. 26 (2003) 145-150.

[33] Okigbo B.N., Greenland D.J. (1992). Intercropping system in Tropical Africa. Journal publishers limited, London, pp. 267.

[34] Olasantan, F.O. and Lucas, E.O. J. Agric. Sci. Tech. 2(1) (1992) 13-22.

[35] Osisanya E.O., Taylor T.O., African Journal of Agricultural Science 1 (1981) 123-141.

[36] Pitan O.O.R., Esan E.O., Archives of Phytopathology and Plant Protection 10 (2013) $1-8$.

[37] Pitan O.O.R., Odebiyi J.A., Crop Protection 20 (2001) 367-372.

[38] Salau A.W., Olasantau F.O., Bodunde J.G., Nigeria Journal of Horticultural Science 17 (2012) 57-67.

[39] Theunissen J., An over view Pesticide Science 45 (1994) 65-68.

[40] Trenbath B.R., Field Crops Research 34 (1993) 381-405.

[41] Thul S.R., Patil R.S., Mule R.S., J. Maharashtra Agric. University 34 (2009) 57-59.

[42] Uddin II R.O., Odebiyi J.A., Journal of Agricultural Science 3(3) (2011) 63-66.

[43] Ukoima H.N., Okah A., Environ. Ecol. 24 (2006) 773-776.

[44] Willey R.W., Natarajan M., Reddy M.S., Rao M.R. (1983). Intercropping studies with annual crops. In: Better crop for food. Nugent, J. and Connor, M. (Eds) Pitman Co. London. 